with the use of the photoelectric cell on the underground railways where the interruption of a beam of light by the train sets the signals; as a burglar alarm, a counting or safety device; to grade manufactured articles according as they are light or dark; for smoke detection and to measure the turbidity or pollution in canals and rivers. Part 2 is concerned with colorimetry. It is emphasized that the photoelectric cell is colour-blind and that it is a robot device. "Its failures in the field of colorimetry are not the shortcomings of the photoelectric cell, but of the operator who is making unreasonable demands upon it." The constructions of the photoemissive and the barrier-layer or photovoltaic cells are described in an appendix, the way in which the latter type of cell works being illustrated pictorially by rabbits in a field near their burrows. For the benefit of those on unfamiliar ground, the booklet is completed by a glossary of terms used.

\section{Municipal Library System of London and the Home Counties}

TнE sixth report of a quinquennial series issued by the Library Association (London and Home Counties Branch) summarizes information regarding the ratesupported municipal library system of London and the Home Counties as existing on March 31, 1949 (pp. 32 ; general editor, James D. Stewart ; London : Central Public Library of Hampstead, 1951). The report covers 119 separate library authorities in the counties of London, Bedford, Berkshire, Buckinghamshire, Essex, Hertford, Kent, Middlesex, Surrey and Sussex, and the information analysed includes all grades of the public library service. The development of the library service in the area over a quarter of a century is traced, and the report is essentially factual : conclusions as to the value and tendencies of details of policy are sparingly drawn. Generally, the service of the area reaches twice as many people as in 1924; issues of books are more than four and a quarter times more numerous; its stock of books has increased more than fourfold; and there are nearly five times as many registered readers as in 1924 .

\section{Certificates and Diplomas in Management Studies}

THE British Institute of Management was established in September 1947 and, early in 1949, under. took to administer jointly with the Ministry of Education a national scheme of management studies, the Institute acting as the co-ordinating authority for the various professional bodies concerned. Regulations covering the national scheme agreed to jointly by the Ministry and the British Institute of Management, and the Scottish Education Depart. ment and the British Institute of Management, were published in 1949 and 1950 and, since that time, technical colleges have been changing over to the new scheme. The majority of professional management bodies agreed to accept a common intermediate certificate in place of their own examinations, while the professional technical institutions which include management studies in their requirements are prepared to grant certain exemptions. Now it may be said that the intermediate certificate stage has been successfully launched, and the second stage, the preparation of suitable diplomas for various specialized management organizations, is under consideration. To clarify the present position and to collate existing information, the British Institute of Management has prepared a handbook giving full details of the examinations, a list of institutions accepting the common intermediate examination, and the proposals for the development of diplomas in management studies. The handbook may be obtained from the British Institute of Management, Management House, 8 Hill Street, London, W.1, price 6s. $3 d$.

\section{Announcements}

Dr. C. W. Arces, of the Commonwealth Observatory, Mount Stromlo, Canberra, has been appointed to the Perren chair of astronomy tenable at University College, London, from October 1, or as soon thereafter as possible.

Prof. J. Brontë Gatenby, professor of zoology and comparative anatomy in Trinity College, Dublin, has been appointed visiting professor of zoology in the Faculty of Science, King Farouk University, Alexandria, from October 1.

THE Exhibition on the "Human Factor in Industry", at the Safety, Health and Welfare Museum, Horseferry Road, Westminster, London, S.W.1 (admission free ; 10 a.m.-6 p.m.), which was to have closed on September 29, will remain open until October 19.

Sir George Bembiy Memorial Fund awards, which are considered by administrators representing the Royal Institute of Chemistry, the Society of Chemical Industry and the Institute of Metals, are made at intervals to British scientific research workers, preference being given to investigations relating to the special interests of Sir George Beilby, including problems connected with fuel economy, chemical engineering and metallurgy. In general, the awards are granted to younger men and women for original work done over a period of years. Awards may be made early next year, and the administrators request that their attention be directed to outstanding work of the nature indicated, not later than December 31. All communications should be addressed to the Convener of the Administrators, Sir George Beilby Memorial Fund, Royal Institute of Chemistry, 30 Russell Square, London, W.C.1.

THE eighteenth Christmas Chemical Engineering Symposium, arranged by the Division of Industrial and Engineering Chemistry of the American Chemical Society, will be on the subject of "Nucleation" and will be held at Northwestern University, Chicago, during December 27-28. The programme will be divided into the following four sections : theoretical aspects, and nucleation from the gas, liquid and solid phase respectively. Attendance is open to all; but papers must be sponsored by a member of the American Chemical Society. Communications should be addressed to the chairman of the Papers Committee, C. M. Cooper, Engineering Research Laboratory, Du Pont Experimental Station, Wilmington, Del. Local arrangements are in the hands of Dr. L. F. Stutzman, of Northwestern University, Evanston, Chicago, IIl.

Erratum. In the article entitled "The Development of "Taxonomic Theory since 1851" by J. S. L. Gilmour in Nature of September 8, on p. 402, column 1, a line of type following line 16 has been omitted. The sentence should read: "It can be called phylogenetic only in a secondary sense, namely, that the reason why a particularly natural biological classification can be made at all is the paramount influence of heredity on the characters of living things. ...". 